\title{
A Rational Approach to Inducing Neuronal Differentiation in Embryonic Stem Cells
}

\author{
Tadahide Furuno and Mamoru Nakanishi \\ School of Pharmacy, Aichi Gakuin University \\ Japan
}

\section{Introduction}

ES cells can produce any cell type of a living organism while self-renewing, and have been a favorable tool for cell engineering, transplantation and regenerative medicine (Wobus and Boheler, 2005). There were many issues about the signalling pathways and molecular mechanisms of self-renewal and differentiation in ES cells, however, the discussion has not realized an appropriate goal yet. Thus, it is important to study the signalling pathways, especially in neuronal differentiation, to create a better and novel approach for controlling the differentiation process using mouse model ES cells (Sugimoto et al., 2009; Miyazu et al., 2010). In mouse ES cells, self-renewal and maintenance of pluripotency requires LIF and bone morphogenic proteins (BMPs) (Smith et al., 1988; Williams et al., 1988; Ying et al., 2003). LIF belongs to the cytokine interleukin (IL)-6 family which utilizes the common gp130 receptor for cellular signaling, and LIF signaling is mediated through a low affinity LIF receptor (LIFR $\beta$ ) which forms a heterodimer with the gp130 upon LIF binding (Hibi et al., 1990; Stahl et al., 1994). The formation of a high affinity trimeric complex composed of LIFR $\beta$, gp130, and LIF leads to the activation of the janus kinase (JAK)-signal transducers and activators of transcription (STAT) pathway and the mitogen-activated protein (MAP) kinase pathway (Burdon et al., 2002; Heinrich et al., 2003; Ernst and Jenkins, 2004; Krinstensen et al., 2005). The binding of LIF to LIFR $\beta$-gp130 results in the rapid activation of JAK which in turn phosphorylates tyrosine residues of LIFR $\beta$ and gp130 (Ernst et al., 1996). The phosphorylated tyrosine residues act as binding sites for signaling molecules such as a transcriptional factor STAT3 and a protein tyrosine phosphatase SHP-2 (Heinrich et al., 1998). Recruited STAT3 and SHP-2 are also phosphorylated at tyrosine residues. Phosphorylation of STAT3 promotes the homodimerization through the interaction of the Src homology (SH) 2 domain and the phosphotyrosine domain. The homodimer of STAT3 translocates to the nucleus and functions as a transcriptional factor (Schindler and Darnell, 1995; Darnell, 1997). On the other hand, phosphorylation of SHP-2 generates binding sites for Grb2 and associates with a scaffold protein Grb2-associated binder protein (Gab) 1. The complex subsequently induces the activation of Ras-MAP kinase cascade (Fukada et al., 1996; Van Vactor et al., 1998). Especially, ERKs, which are members of MAP kinase family proteins, are activated by a large number of ligands. The binding of BMP4 to its receptors triggers the phosphorylation of Smad1 and activates the expression of inhibitor of differentiation (Id) gene family. It is considered that the induction of Id expression through Smad1 activation by BMP4 is the critical contribution to the maintenance of pluripotency in 
ES cells (Ying et al., 2003). Hence, mouse ES cells are maintained in an undifferentiated state in vitro with LIF, which activates STAT3 and BMP to induce Id proteins (Niwa et al., 1998; Matsuda et al., 1999; Raz et al., 1999; Ying et al., 2003). As described above, the LIF leads to the phosphorylation of STAT3 and ERKs. Actually the phosphorylation form of STAT3 is detected in undifferentiated ES cells cultured in the medium containing LIF. However, the phosphorylation of ERKs does not occur in undifferentiated ES cells. The activation of ERKs is considered to be involved in the differentiation process rather than the maintenance of undifferentiated state, because the removal of LIF leads to the phosphorylation of ERKs and the attenuation of ERKs activation by inhibitor of a MAP/ERK kinase (MEK) activation or expression of ERK phosphatases reduced the level of differentiation of ES cells (Burdon et al., 1999a). Therefore, in ES cells, it has been considered that LIF predominantly activates STAT3 to remain undifferentiated and that the balance of conflicting activation of STAT3 and ERKs might determine the efficiency of the self-renewal and differentiation (Niwa et al., 1998; Burdon et al., 1999b). However, the molecular mechanism for balanced activation of STAT3 and ERKs in ES cells is not yet clear. We recently found that the dephosphorylation of phospho-STAT3 and phosphorylation of ERKs occurred consistently after the removal of LIF and that SOCS3, whose expression was regulated by STAT3, might regulate the activation of ERK pathway (Miyazu et al., 2010).

On the other hand, the removal of LIF is known to induce the formation of EB for ES cells. The most commonly used approach for neural differentiation from ES cells is the formation of EB and the treatment of EB with retinoic acid (Strubing et al., 1995). It has been reported that ES cells overexpressing NeuroD2, a basic helix-loop-helix (bHLH) transcriptional factor, lead to differentiation to neurons efficiently in the absence of retinoic acid after EB formation (Kanda et al., 2004). Because continued culture of EB results in the appearance of ectodermal, mesodermal, and endodermal cell types, the differentiation of EB yields a small fraction of neural cells. The establishment of differentiation system from ES cells to neurons without EB formation is considered to be favorable for the production of neurons in high efficiency. The bHLH transcriptional factors are implicated in the regulation of differentiation in various cell types (Massari and Murre, 2000). NeuroD2 has been reported to play a critical role in the induction of neuronal differentiation, the promotion of neuronal survival, and development of thalamocortical communication (Kume et al., 1996; McCormick et al., 1996; Yasunami et al., 1996; Farah et al., 2000; Olson et al., 2001; InceDunn, et al., 2006; Lin et al., 2006; Noda et al., 2006). NeuroD2 has two basic-rich domains; one is basic region of bHLH and the other is nuclear localization signal which plays a role of protein transduction. In Xenopus laevis embryos the expression of NeuroD2 results in ectopic neurogenesis, and in mouse brain NeuroD2 expression starts around embryonic day 11. NeuroD2-deficient mice exhibit small brains, ataxia, reduced seizure threshold, defective thalamacortical synapses, growth failure, and early death. NeuroD2 also induces the differentiation to neurons in mouse neuroblastoma cells, embryonic carcinoma cells, and ES cells (Farah et al., 2000; Kanda et al., 2004; Noda et al., 2006).

Then, we recently established the regulation system of NeuroD2 expression using doxycycline in ES cells (Gossen and Bujard, 1992; Gossen and Bujard, 1995). This system was useful for studying the role of NeuroD2 in the neuronal differentiation because specific transcriptional factors are known to be expressed in a manner consistent with their having a regulatory role in the various stages of ES cell development (Sugimoto et al., 2009). So, in this review we will describe focusing mainly on the SOCS3 signalling and expression of Neuro D2 in mouse ES cells. 


\section{Materials and methods}

\subsection{Cell cultures}

Mouse 129/sv ES cell lines (passage 15, Dainippon Pharmaceutical Corporation, Osaka, Japan) were routinely cultured on tissue culture plates (Falcon) coated with $0.1 \%(\mathrm{v} / \mathrm{v})$ gelatin (Dainippon Pharmaceutical Corporation) in Knockout ${ }^{\mathrm{TM}}$ Dulbecco's modified Eagle's medium (DMEM) (Invitrogen, Scottland) in the presence of 15\% (v/v) Knockout ${ }^{\mathrm{TM}}$ serum replacement (Invitrogen), $0.1 \mathrm{mM} \beta$-mercaptoethanol, $2 \mathrm{mM}$ L-glutamine, $0.1 \mathrm{mM}$ non-essential amino acids, 100 units $/ \mathrm{ml}$ penicillin, $0.1 \mathrm{mg} / \mathrm{ml}$ streptomycin, and 1000 units $/ \mathrm{ml}$ mouse LIF (Chemicon) in $5 \% \mathrm{CO}_{2}$ incubator at $37^{\circ} \mathrm{C}$ (Amano et al., 2006; Sugimoto et al., 2009; Miyazu et al., 2010). Cells were trypsinized and replated every 3 days.

\subsection{Western blotting}

To prepare whole cell lysate, collected ES cells were suspended in ice-cold lysis buffer (10 $\mathrm{mM}$ Tris- $\mathrm{HCl}, \mathrm{pH}$ 7.4, 0.5\% Nonidet P-40, $1 \mathrm{mM}$ EDTA, $150 \mathrm{mM} \mathrm{NaCl}, 1 \mathrm{mM} \mathrm{Na} 3 \mathrm{VO}_{4}, 0.5$ $\mathrm{mM}$ phenylmethylsulfonyl fluoride) and allowed to stand on ice for $30 \mathrm{~min}$. The suspension was clarified by centrifugation $(14,000 \mathrm{rpm}, 20 \mathrm{~min})$. After centrifugation, the resulting supernatants were solubilized by treatment with Laemmli buffer at $100^{\circ} \mathrm{C}$ for $5 \mathrm{~min}$ and separated by electrophoresis in 10\% SDS-polyacrylamide gel. The electrophoresed proteins were transferred to polyvinylidene difluoride membranes with an electroblotter. After blocking with $5 \%$ skim milk, the membranes were probed with rabbit anti-phospho STAT3 (Tyr705) antibody (Cell Signaling) (1:1000 dilution), rabbit anti-STAT3 antibody (Cell Signaling) (1:1000 dilution), rabbit anti-phospho c-Raf (Ser338) antibody (Cell Signaling) (1:200), rabbit anti-phospho MEK1/2 (Ser217/221) antibody (Cell Signaling) (1:500), rabbit anti-phospho p44/p42 MAP kinase (Thr202/Tyr204) antibody (Cell Signaling) (1:500), rabbit anti-p44/p42 MAP kinase antibody (Cell Signaling) (1:1000), goat anti-SOCS3 antibody (M20) (Santa Cruz Biotechnology) (1:100) or rabbit anti- $\beta$-actin antibody (clone AC-15) (Sigma) (1:5000 dilution) and treated with 1:1000 dilution HRP-conjugated anti-rabbit IgG (Santa Cruz Biotechnology) or HRP-conjugated donkey anti-goat IgG (Santa Cruz Biotechnology). The amount of HRP-conjugated IgG bound to each protein band was determined by LAS1000 (Fuji Film, Tokyo, Japan) and analyzed by Image Gauge (Fuji Film). The pixel density in each band was corrected by that in the control protein (STAT3, ERKs or $\beta$-actin).

\subsection{Immunostaining}

ES cells were washed with ice-cold TBS buffer $(25 \mathrm{mM}$ Tris, pH 7.4, $137 \mathrm{mM} \mathrm{NaCl}$, and 2.68 $\mathrm{mM} \mathrm{KCl}$ ), attached to microscope slides by Cytospin 4 centrifugation (Thermo Shandon, Pittsburgh, USA) (1,000 rpm, $5 \mathrm{~min}$ ), and fixed with $4 \%$ paraformaldehyde for $15 \mathrm{~min}$. They were permeabilized with $0.2 \%$ Triton X-100 for $5 \mathrm{~min}$, and blocked with $1 \%$ bovine serum albumin for $30 \mathrm{~min}$. For single staining, fixed cells were incubated with the rabbit antiphospho STAT3 (Tyr705) antibody (1:100) or rabbit anti-phospho p44/p42 MAP kinase (Thr202/Tyr204) antibody (1:100), rabbit anti-MAP2 antibody (1:400) (Santa Cruz Biotechnology), or rabbit anti-NeuroD2 antibody (1:100) (Sigma), and stained with FITCconjugated goat anti-rabbit IgG antibody $(10 \mu \mathrm{g} / \mathrm{ml})$ (ICN Pharmaceticals, USA). For double staining, fixed cells were incubated with goat anti-SOCS3 antibody (M-20) (1:50) and stained with rhodamine-conjugated donkey anti-goat IgG $(10 \mu \mathrm{g} / \mathrm{ml})$ (Santa Cruz Biotehnology). Then, the samples were incubated with rabbit anti-phospho MEK1/2 (Ser217/221) antibody (1:200) and stained with FITC-conjugated goat anti-rabbit IgG 
antibody $(10 \mu \mathrm{g} / \mathrm{ml})$. For staining of nucleus, fixed cells were incubated with propidium iodide $(1 \mu \mathrm{g} / \mathrm{ml})$ (Sigma). Cells were visualized using a confocal laser scanning microscope (CLSM) (LSM510; Carl Zeiss, OberKochen, Germany) (Furuno et al., 1993; Nakanishi, 2003; Nakanishi and Furuno, 2008). FITC was excited at $488 \mathrm{~nm}$ by an argon ion laser and its fluorescence was detected through a long pass filter $(>505 \mathrm{~nm})$ for the single staining. In the case of double staining, FITC and rhodamine were excited at $488 \mathrm{~nm}$ by an argon ion laser and at $543 \mathrm{~nm}$ by a He-Ne laser, respectively. Their fluorescence was detected through a band pass filter (505 - $530 \mathrm{~nm}$ ) and a long pass filter (> $560 \mathrm{~nm}$ ), respectively (Suzuki et al., 2004; Furuno et al., 2005).

\subsection{Establishment of cell lines}

The ES cells $\left(1 \times 10^{7}\right.$ cells / $\left.500 \mu \mathrm{l}\right)$ were electroporated in cold $\mathrm{K}^{+}-\mathrm{PBS}$ with $30 \mu \mathrm{g}$ of pTet-On plasmid DNA (Clontech Laboratories, Palo Alto, CA, USA) at $220 \mathrm{~V}$ and $475 \mu \mathrm{F}$ using Gene Pulser (Bio-Rad, Richmond, CA). ES cells transfected with pTet-On were maintained in culture dishes for $48 \mathrm{~h}$ and were cloned by the selection with antibiotic G418 (Sigma). To investigate the expression of reverse tetracycline-controlled transactivator (rtTA) in monoclonal ES cells (rtTA-ES cells), luciferase was assayed after the transfection of the plasmid DNA containing tetracycline response element (TRE) to express luciferase (pTRELuc) (Clontech).

To obtain NeuroD2 cDNA, poly(A)+ RNA was prepared with a Quickprep Micro mRNA Purification Kit (Amersham Biosciences, Little Chalfont, Buckinghamshire, UK) from mouse cerebellum and served as templates for cDNA synthesis with SuperScript II RT (Invitrogen Corp., Carlsbad, CA, USA). The DNA sequences coding NeuroD2 (GEN Bank accession number: U58471) was obtained by RT-PCR with appropriate primer pairs, 5'GTCGACATGCTGACCCGCCTGTTC-3' (sense; Acc I site is italicized) / $5^{\prime}$ CCGCGGTCAGTTATGGAAAAATGCGTTGA-3' (antisense; Sac II site is italicized) using a Taq polymerase EX-Taq (Takara, Tokyo, Japan). The PCR products were subcloned into a TA cloning vector pCRII (Invitrogen) and sequenced with an Applied Biosystems 3130xl genetic analyzer to verify the DNA sequence of NeuroD2. The full-length cDNA coding NeuroD2 was ligated with pTRE-Hyg2 expression vector (Clontech) at Acc I and Sac II sites (pTRE-ND2). pTRE-ND2 plasmid DNA $(30 \mu \mathrm{g})$ was electroporated to rtTA-ES cells $\left(1 \times 10^{7}\right.$ cells $/ 500 \mu \mathrm{l})$, and trandfected ES cells were cultured for $48 \mathrm{hr}$ and then were selected by antibiotic Hygromycin B (Sugimoto et al., 2009).

For genomic DNA PCR, genome DNA was isolated from ES cells $\left(5 \times 10^{6}\right.$ cells) with a Blood and Cell Culture Kit (Qiagen). For RT-PCR, mRNAs were purified from ES cells with a Quickprep Micro mRNA Purification Kit (Amersham Biosciences) and served as templates for cDNA synthesis with SuperScript II RT (Invitrogen). Genomic DNA and cDNA were amplified by PCR using appropriate primers and a Taq polymerase EX-Taq (Takara).

The rtTA-ES cells were transfected with pTRE-Luc and were cultured for $48 \mathrm{hr}$ in the presence or absence of doxycycline $(1 \mu \mathrm{g} / \mathrm{ml})$. Then, the cells were washed three times with PBS and lysed in a cell lysis buffer. The lysate was centrifuged at $12,000 \times \mathrm{g}$ at $4{ }^{\circ} \mathrm{C}$ for $3 \mathrm{~min}$ and supernatant was subjected to a luciferase assay. The luciferase assay was carried out using a picagene luciferase assay kit (Toyo Ink, Tokyo, Japan). The relative light unit of chemiluminescence was measured with a luminometer (TD-20/20; Turner Designs; Sunnyvale, CA, USA) and the values were normalized to the amount of protein determined by BCA assay (Inoh et al., 2001). 


\subsection{Alkaline phosphatase assay}

After washing, ES cells were fixed with $4 \%$ paraformaldehyde for $15 \mathrm{~min}$ at $4{ }^{\circ} \mathrm{C}$ and stained with NBT-BCIP solution (Sigma). After incubation for $30 \mathrm{~min}$ at $37{ }^{\circ} \mathrm{C}$, the reaction was stopped by EDTA $(10 \mathrm{mM})$. The cells were washed with PBS and examined microscopically.

\subsection{Data analysis}

Data were presented as mean \pm SEM. In statistical analysis, data were analyzed by unpaired Student's $t$-test, 2 -tailed. $P<0.05$ were accepted as a level of statistically significant difference.

\section{Results}

\subsection{The relationship between dephosphorylation of phospho-STAT3 and phosphorylation of ERKs}

To examine the relationship between activation of STAT3 and ERKs in the differentiation processes in mouse ES cells, we studied time-courses of phosphorylation of STAT3, ERKs, and Raf-1, which is a kinase that acts upstream of the ERK signaling cascade after the removal of LIF. In the presence of LIF, STAT3 was strongly phosphorylated in mouse ES cells, but Raf-1 and ERKs in the same cells were not phosphorylated, as described in previous papers (Qu et al., 1997; Burdon et al., 1999a; Matsuda et al., 1999; Jirmanova et al., 2002; Chan et al., 2003; Yao et al., 2003). When LIF was removed from the culture medium, the level of phospho-STAT3 was decreased, but those of phospho-Raf-1, -MEK, and -ERKs were increased, as shown in Fig. 1a. The level of phospho-STAT3 reached the minimum at $4 \mathrm{~h}$ after the removal of LIF, and then, it increased again. In contrast, the phosphorylation of Raf-1 reached the maximum at $\sim 4 \mathrm{~h}$, and then decreased to the basal level. The phosphorylation of MEK occurred slowly, and ERKs were subsequently phosphorylated. These results suggested that the time-course of dephosphorylation of phospho-STAT3 was consistent with that of phosphorylation of Raf-1 and that the ERKs were phosphorylated with a lag period after the Raf- 1 activation. In addition, immunostaining analysis showed that the fluorescence intensity of phospho-STAT3 in the nucleus in ES cells, which was high in the presence of LIF, decreased at $4 \mathrm{~h}$ and then became high at $72 \mathrm{~h}$ again after the removal of LIF. On the other hand, the fluorescence intensity of phospho-ERKs increased at $12 \mathrm{~h}$, and fell to the basal level at $72 \mathrm{~h}$. These immunostaining images were corresponding to the data of phosphorylation level observed by Western blotting. These suggested that the removal of LIF led to the differentiation of ES cells by the spatiotemporally balanced activation of STAT3 and ERKs.

\subsection{Link of STAT3 and ERKs signaling pathways}

Though the phosphorylation of ERKs was detected in ES cells after the removal of LIF, LIF was essentially known to activate the ERK signaling cascade. To study whether STAT3 and ERKs were phosphorylated by LIF stimulation in ES cells, we analyzed the phosphorylations of STAT3 and ERKs after the addition of LIF in ES cells which were precultured in the absence of LIF for $4 \mathrm{hr}$. LIF induced to the phosphorylation of ERKs as well as STAT3 within $10 \mathrm{~min}$ in LIF-starved ES cells. The LIF-mediated phosphorylation of STAT3 lasted $30 \mathrm{~min}$, whereas that of ERKs was transient and almost disappeared at $30 \mathrm{~min}$. Next, to examine the effects of signaling proteins in the ERK signaling cascade on the STAT3 activation, we studied the LIF-mediated phosphorylations of STAT3 and ERKs in LIFstarved ES cells pretreated with a MEK inhibitor PD98059 $(20 \mu \mathrm{M})$ for $30 \mathrm{~min}$ (Alessi et al., 
1995; Furuno et al., 2001). The pretreatment of PD98059 inhibited ERKs phosphorylation after LIF stimulation but not STAT3 phosphorylation. This suggested that the activation level of ERK did not affect the phosphorylation of STAT3. Next, to examine the effects of STAT3 transcriptional activity on the activation of ERKs in ES cells, we investigated the phosphorylation level of ERKs in ES cells cultured in the medium containing LIF and STAT3 inhibitory peptide (STAT3IP) $(10 \mu \mathrm{M})$, a membrane-permeable inhibitor of STAT3 dimerization (Turkson et al., 2004). When ES cells were cultured in the presence of LIF in the medium containing STAT3IP $(10 \mu \mathrm{M})$ for 4 days, the phosphorylation of ERKs was found to be accelerated. In contrast, the phosphorylation level of STAT3 was decreased. Immunostaining analysis also showed the increase in fluorescence intensity in the nucleus of phospho-ERKs and the decrease in that of phospho-STAT3 by the treatment with STAT3IP $(10 \mu \mathrm{M})$ for 4 days. These indicated that STAT3IP led to the phosphorylation of

(a)

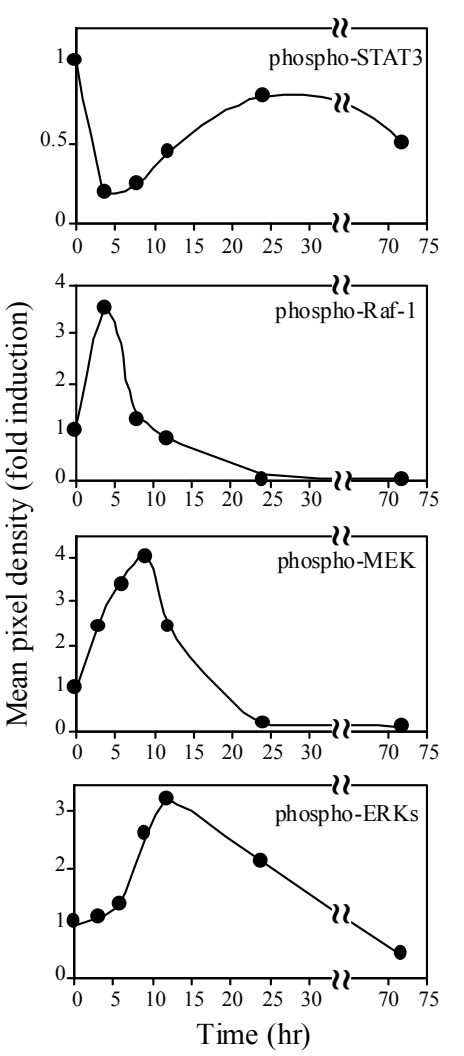

(b)

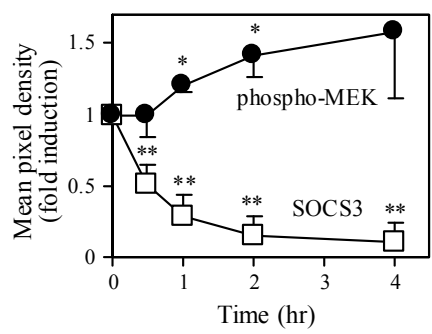

(c)

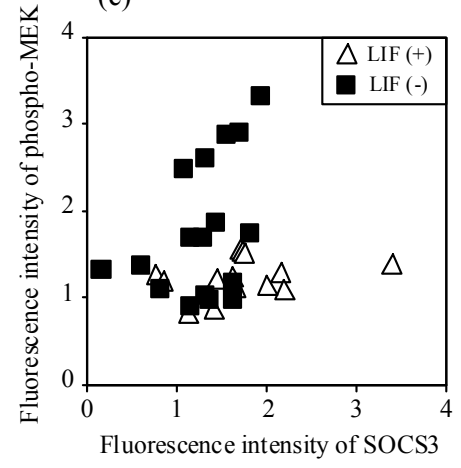

Fig. 1. Phosphorylation states of STAT3 and MAP kinase cascade. (a) The balanced phosphorylation of STAT3, Raf-1, MEK, and ERKs in ES cells after the removal of LIF. (b) The correspondence between the expression of SOCS3 and the phosphorylation of MEK after the removal of LIF. ${ }^{*} \mathrm{P}<0.05$ and ${ }^{* *} \mathrm{P}<0.01$ compared to the value at $0 \mathrm{~h}$. (c) The relation between the expression of SOCS3 and the phosphorylation of MEK at $4 \mathrm{~h}$ after the removal of LIF in individual ES cells. 
ERKs and the dephosphorylation of STAT3, and that STAT3IP disrupted the balance of the activation of STAT3 and ERKs in ES cells cultured in LIF-containing medium. From the result, the reason why the phosphorylation level of ERKs was not detected in undifferentiated ES cells in the presence of LIF was guessed to be due to the high transcriptional activity of STAT3 mediated by LIF.

\subsection{Involvement of SOCS3 in STAT3IP-mediated ERKs phosphorylation}

We focused SOCS3 as a molecule involved in STAT3IP-mediated ERKs phosphorylation because the expression of SOCS3 was induced by cytokines including LIF probably through STAT3, and SOCS3 could also act to suppress ERK signaling by competing with SHP-2 for binding to the phosphotyrosine of gp130 (Bousquet et al., 1999; Duval et al., 2000; Nicholson et al., 2000; Schmitz et al., 2000). To confirm that LIF could induce the expression of SOCS3 in ES cells, we examined the expression of SOCS3 after the addition of LIF to LIF-starved ES cells. The expression of SOCS3 was not detected in LIF-starved ES cells, but it increased gradually after the addition of LIF. The pretreatment of LIF-starved ES cells for 60 min with STAT3IP $(10 \mu \mathrm{M})$ suppressed the LIF-mediated expression of SOCS3.

Then, we studied the expression of SOCS3 in ES cells cultured in the presence of LIF. We found that SOCS3 was expressed in undifferentiated ES cells and that the removal of LIF reduced the expression of SOCS3 time-dependently, as shown in Fig. 1b. SOCS3 was almost undetectable in ES cells at $4 \mathrm{~h}$ after the removal of LIF. In contrast, the phosphorylation of MEK proceeded according to the decrease in expression of SOCS3 (Fig. 1b). In addition, double-immunostaining analysis of SOCS3 and phospho-MEK in individual ES cells also showed that SOCS3, which distributed on the plasma membrane, was diminished, and the phosphorylation of MEK increased in the cytoplasm at $4 \mathrm{~h}$ after the removal of LIF. In scatter plotting to analyze the correspondence between the expression of SOCS3 and the phophorylation of MEK in individual ES cells, it was shown that the phosphorylation of MEK proceeded in cells where the expression of SOCS3 was down-regulated $4 \mathrm{~h}$ after removal of LIF (Fig. 1c). These results strongly suggested that SOCS3, whose expression was regulated by STAT3 transcriptional activity, suppressed the activation of the ERK pathway.

\subsection{Establishment of ES cells stably transfected with pTet-On plasmid DNA}

As described above, the removal of LIF led to decrease the expression of SOCS3 and activate the ERK cascade in mouse ES cells. This phenomenon is probably the first step for ES cells to differentiate into many kinds of cell types, but it is also important to induce the differentiation into a specific target cell type in high efficiency. Here we tried to differentiate ES cells into neuronal cells using control system of NeuroD2 expression. First, to establish ES cells where the expression of NeuroD2 was regulated by doxycycline, mouse ES cell lines were transfected by electroporation with a pTet-On plasmid DNA. We obtained 21 monoclonal ES cell lines resistant to G418 and investigated the transfection of pTet-On in genomic DNA. PCR for genomic DNA showed that the transfection of pTet-On was detected in the clone \#9 ES cell (rtTA-ES cell), as shown in Fig. 2a. When pTRE-Luc plasmid DNA was temporally introduced to rtTA-ES cells, the clone \#9 rtTA-ES cell had the highest luciferase activity after the addition of doxycycline among other clones. Thereafter, we transfected pTRE-ND2 plasmid DNA to the clone \#9 rtTA-ES cell line and cultured them in the presence of Hygromycin B. After selection by Hygromycin B, polyclonal TRE-ND2-ES cells where pTRE-ND2 was stably transfected were established. Transfection of pTRE-ND2 
in genomic DNA was detected in TRE-ND2-ES cells but not in wild type ES cells, as shown in Fig. 2b. TRE-ND2-ES cells also showed alkaline phosphatase activity and Oct3/4 expression, which are features of an undifferentiated state of ES cells, similar to wild type ES cells. These findings indicate that TRE-ND2-ES cells were maintained in an undifferentiated state.

\subsection{Expression of NeuroD2 in ES cells after the addition of doxycycline}

Next, we confirmed the induction of NeuroD2 expression in TRE-ND2-ES cells by the addition of doxycycline by following mRNA and protein levels. A marked increase in mRNA for NeuroD2 was detected in TRE-ND2-ES cells at $24 \mathrm{~h}$ after doxycycline addition by RT-PCR. CLSM images showed that the treatment with doxycycline for $24 \mathrm{hr}$ also led to express NeuroD2 protein in most TRE-ND2-ES cells, as shown in Fig. 2c. The NeuroD2 expression was observed in TRE-ND2-ES cells treated for $48 \mathrm{hr}$ to a similar extent. The results show that doxycycline induced the expression of NeuroD2 in TRE-ND2-ES cells.

(a)
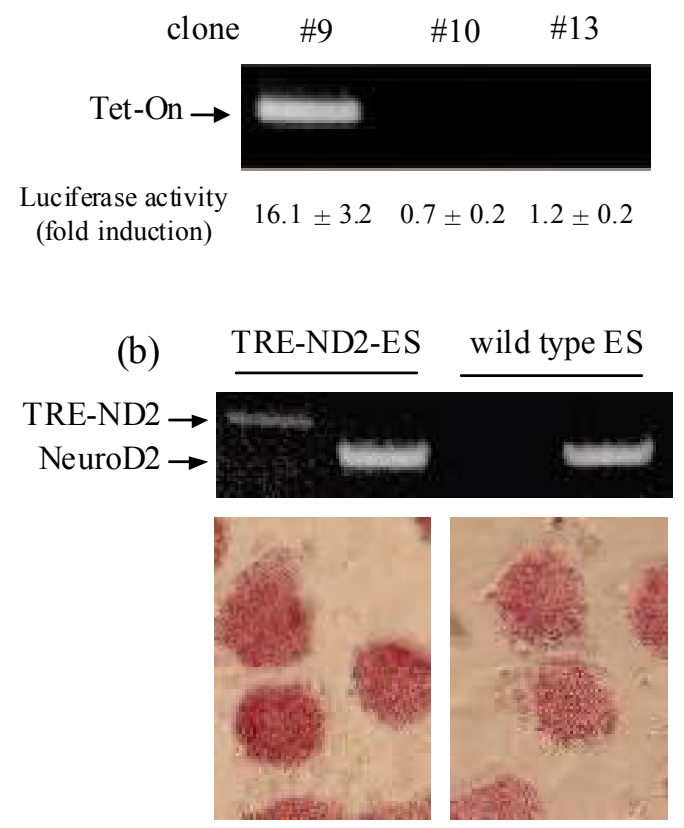

(c)
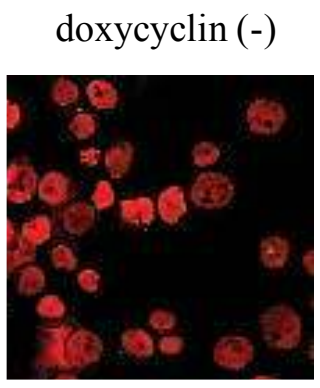

doxycyclin $(+)$

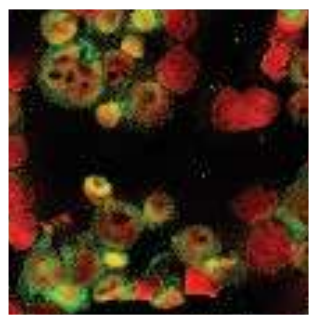

Fig. 2. Establishment of ES cell lines where the expression of NeuroD2 is regulated by doxycycline. (a) A genomic DNA PCR in ES cell clones transfected with pTet-On (rtTA-ES cells). Fold induction of luciferase activity was shown as the value at $24 \mathrm{~h}$ after doxycycline addition divided by it at $0 \mathrm{~h}$. (b) A genomic DNA PCR (upper) and an alkaline phosphatase staining (lower) in rtTA-ES cells transfected with pTRE-ND2 (TRE-ND2-ES cells) and wild type ES cells. (c) Immunostaining of NeuroD2 in TRE-ND2-ES cells. Fluorescence derived from NeuroD2 (green) and nucleus (red) was observed in cells treated without and with doxycycline for $24 \mathrm{~h}$. 


\subsection{Differentiation into neurons after the addition of doxycycline}

To check that the induction of NeuroD2 expression elicits the neuronal differentiation, TREND2-ES cells were immunostained with MAP2, a marker protein of neurons. MAP2-positive neuronal cells were significantly developed without formation of EB after 7 days of doxycycline addition, although some spontaneous differentiation was observed in the absence of doxycycline. The fluorescence intensity derived from MAP2 was significantly increased by doxycycline, as shown in Fig. 3. Thus doxycycline-induced NeuroD2 expression leads to neuronal development in TRE-ND2-ES cells.

Finally, we investigated the period of treatment with doxycycline needed to induce clear evidence of neuronal differentiation. MAP2-positive cells were followed over 11 days of culturing; by day 3 of treatment there was sufficient evidence that differentiation into neurons had taken place. Treatment with doxycycline for 1 day did not induce the neuronal differentiation efficiently. In addition, CLSM images showed that NeuroD2 was localized in the cytoplasm but not in the nucleus on day 1 , and thereafter proceeded gradually into the nucleus. The expression of NeuroD2 for an appropriate period ( $\sim 3$ days) was therefore necessary for the neuronal differentiation and its intracellular distribution also affected the efficiency of differentiation into neurons.

\section{doxycycline}
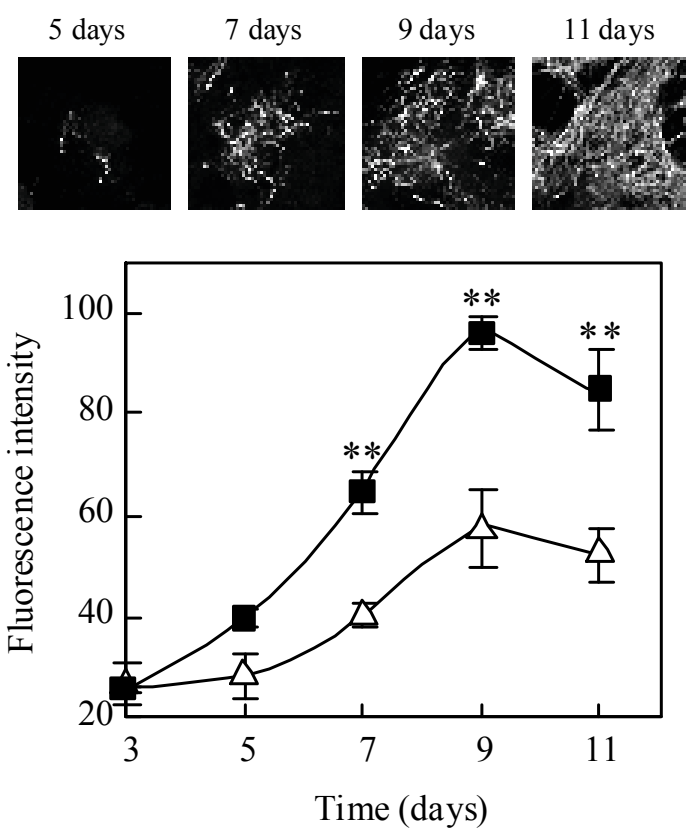

Fig. 3. Differentiation into neurons by doxycycline in TRE-ND2-ES cells. (Upper) Immunostaining of MAP2 in TRE-ND2-ES cells cultured in the presence of doxycycline (100 $\mu \mathrm{M})$. (Lower) Fluorescence intensity derived from MAP2 in region of interest (ROI) of CLSM images. Averaged fluorescence intensity in ROI was measured from 10 images of TRE-ND2ES cells cultured in the presence (closed squares) and absence (open triangles) of doxycycline. ${ }^{* *} \mathrm{P}<0.01$ compared to cells without treatment of doxycycline. 


\section{Discussion}

LIF is a member of the family of IL-6 type cytokines, which includes IL-6, IL-11, oncostatin $\mathrm{M}$, ciliary neurotrophic factor, and cardiotrophin-1, and leads to the activation of JAK-STAT and ERK pathways through LIFR $\beta$-gp130 receptors. Because LIF also plays a crucial role in self-renewal and maintenance of pulripotency in mouse ES cells, it is widely used for their propagation. However, STAT3 is constitutively phosphorylated in undifferentiated ES cells in the presence of LIF and functions to maintain their undifferentiated state and pluripotency, but the phosphorylation of ERKs is not detected. The removal of LIF induces not only the dephosphorylation of phospho-STAT3 but also the phosphorylation of ERKs and directs ES cells to differentiate. Therefore, it has been considered that some important connections between the STAT3 and ERK pathways exist in ES cells, but the relationship between those pathways in the process of ES cell differentiation has not been analyzed in detail.

At first, we found that the amount of phospho-STAT3 decreased at $\sim 4 \mathrm{hr}$ after the removal of LIF and then gradually increased at $24 \mathrm{hr}$ (Fig. 1). The phosphorylation of Raf-1 occurred at $\sim 4 \mathrm{hr}$, and thereafter MEK and ERKs were subsequently phosphorylated at 8 $12 \mathrm{~h}$ and immediately dephosphorylated. The time-courses of the phosphorylation levels of STAT3 and Raf-1 suggested the interaction between STAT3 and ERK pathways in ES cells. It was reported that the inhibition of ERKs activity resulted in the enhancement of STAT3mediated transcription in previous papers (Bonni et al., 1997; Ihara et al., 1997; Sengupta et al., 1998). However, the pretreatment with PD98059 affected neither the phosphorylation of STAT3 by LIF addition nor the dephosphorylation of phospho-STAT3 by LIF removal in our present condition. On the other hand, a membrane-permeable inhibitor of STAT3 dimerization, STAT3IP, accelerated ERKs phosphorylation in ES cells cultured in the presence of LIF. These suggested that the phosphorylation of ERK did not affect STAT3 activation, but that the transcriptional activity of STAT3 regulated the ERK activation. From these results, it was considered that the inactivation of STAT3 by the removal of LIF would trigger the activation of the ERKs pathway in ES cells (Miyazu et al., 2010).

We showed here that the expression of SOCS3 depended on the presence of LIF in ES cells. The expression of SOCS3 was increased by the addition of LIF and decreased by the removal of LIF (Fig.1). SOCS3 is reported to exhibit inhibitory function of ERK signaling through the SHP-2 binding site of gp130 (Schmitz et al., 2000). The phosphorylation of MEK was actually promoted in ES cells expressing less SOCS3 in our present results (Fig. 1). In addition, it was reported that the absence of SOCS3 perturbed the balance of activation between STAT3 and ERK pathways and induced the reduction of self-renewal and the promotion of differentiation in ES cells (Forrai et al., 2006). Our data indicated the possibility that SOCS3, which is expressed by constitutively activated STAT3 in the presence of LIF in undifferentiated ES cells, suppressed the activation of ERK pathway, and that the reduction of SOCS3 expression as a result of dephosphorylation of phospho-STAT3 after LIF removal activated ERKs activation and became a trigger for differentiation in mouse ES cells.

Because several signaling pathways are involved in propagation, maintenance of pluripotency, and differentiation in ES cells, its signaling and transcriptional network is very complicated (Chen et al., 2008). Other signaling molecules such as glycogen synthase kinase (GSK) 3 and transcriptional factors including Nanog, Oct-4, Smad1, and NF-kB in addition to ERKs, SOCS3, and STAT3 described in this paper, play important roles in mouse ES cells (Torres and Watt, 2008; Ying et al., 2008). On the other hand, it was reported that ERK 
signals contributed to the maintenance of self-renewal, and LIF/STAT3 signaling was independent of maintenance of pluripotency in human ES cells (Okita and Yamanaka, 2006; Li et al., 2007). Accordingly, because the signaling pathway to maintain pluripotency and to induce differentiation in mouse ES cells may be different in human ES cells, the experiments to study the signaling pathway in human ES cells are necessary. In any case, the role of SOCS3 in ES cell differentiation needs to be defined in more detail, and our data strongly suggested that SOCS3 is intimately involved in the regulation of balanced activation between the STAT3 and ERK pathways in LIF signaling in mouse ES cells.

In addition, we have tried to get ES cells to differentiate into neurons after the addition of doxycycline using NeuroD2, a bHLH transcriptional factor. NeuroD2 induces ectopic neurogenesis in the ectodermal cells in Xenopus embryos and neuronal differentiation in mammalian embryonal carcinoma cells (McCormick et al., 1996; Farah et al., 2000). We have shown that doxycycline induced the expression of NeuroD2 in TRE-ND2-ES cells and that the inducible NeuroD2 expression leads after several days to differentiation into neurons without formation of EBs. Addition of doxycycline significantly promotes neuronal differentiation in TRE-ND2-ES cells (see Fig. 2). About half the cells expressed NeuroD2 after the addition of doxycycline, but the yield of MAP2-positive cells was $25-30 \%$. It is known that extracellular matrices affect neural differentiation and growth, and that ES cells cultured on the dishes coated with laminin or fibronectin can be effectively differentiated into neurons (Czyz and Wobus, 2001; Andressen et al., 2005). In addition, several factors such as retinoic acid, basic fibroblast growth factor, sonic hedgehog, bone morphogenetic proteins, and Wnt can also play important roles in accelerating neuronal differentiation (Du and Zhang, 2004; Murashov et al., 2005). To study the essential role of NeuroD2 in neuronal differentiation, we cultured ES cells in gelatin-coated dishes in the absence of supplements such as growth factors and mitogen, in which the efficiency and specificity of differentiation was not completely satisfactory in view of transplantation and regenerative medicine. However, the combination of NeuroD2 expression and growth factor/mitogen addition does increase the specificity and efficiency of neural differentiation in ES cells.

Doxycycline-induced neurons extended long neurites and formed dense neurite network. The number of MAP2-positive neurons reached a plateau at 3, while the MAP2-derived signal increased from 3 to 9 days. This means that ES cells are differentiated into neurons within 3 days after doxycycline addition, and that the differentiated neurons thereafter show neurite extension and network formation. However, although some ES cells spontaneously differentiated into neurons without doxycycline in this experimental condition, their neurites were thin and extend of their outgrowth was small. NeuroD2 was distributed in the cytoplasm of ES cells 1 day after the treatment with doxycycline, but if NeuroD2 could be translocated to the nucleus by some treatment (e.g. cytokines or growth factors), ES cells would be differentiated into neurons without the formation of EB, and raise the possibility of the induction of neuronal differentiation of ES cells in high efficiency by NeuroD2.

\section{Conclusion}

It is indicated that SOCS3 is involved in maintaining an undifferentiated state mediated by LIF and that the extrinsic expression of NeuroD2 efficiently induced differentiation into neurons in mouse ES cells. These findings provide the possibility to lead to the specific differentiation into target cell types for ES cells. 


\section{References}

Alessi, DR.; Cuenda, A., Cohen, P., Dudley, DT. \& Saltiel, AR. (1995). PD 98059 is a specific inhibitor of the activation of mitogen-activated protein kinase kinase in vitro and in vivo. J. Biol. Chem., 270, 27489-27494.

Amano, K.; Furuno, T. \& Nakanishi, M. (2006). Conditioned medium from feeder STO cells increases the attachment of mouse embryonic stem cells. Biol. Pharm. Bull., 29, 17471750.

Andressen, C., Adrian, S., Fassler, R., Arnhold, S. \& Addicks, K. (2005). The contribution of beta1 integrins to neuronal migration and differentiation depends on extracellular matrix molecules. Eur. J. Cell Biol., 84, 973-982.

Bonni, A.; Sun, Y., Nadal-Vicens, M., Bhatt, A., Frank, DA., Rozovsky, I., Stahl, N., Yancopoulos, GD. \& Greenberg, ME. (1997). Regulation of gliogenesis in the central nervous system by the JAK-STAT signaling pathway. Science, 278, 477-483.

Bousquet, C.; Susini, C. \& Melmed, S. (1999). Inhibitory roles for SHP-1 and SOCS-3 following pituitary proopiomelanocortin induction by leukemia inhibitory factor. $J$. Clin. Invest., 104, 1277-1285.

Burdon, T.; Chambers, I., Stracey, C., Niwa, H. \& Smith, A. (1999b). Signaling mechanisms regulating self-renewal and differentiation of pluripotent embryonic stem cells. Cells Tissues Organs, 165, 131-143.

Burdon, T.; Smith, A. \& Savatier, P. (2002). Signalling, cell cycle and pluripotency in embryonic stem cells. Trends Cell Biol., 12, 432-438.

Burdon, T.; Stracey, C., Chambers, I., Nichols, J. \& Smith, A. (1999a). Suppression of SHP-2 and ERK signalling promotes self-renewal of mouse embryonic stem cells. Dev. Biol., 210, 30-43.

Chan. RJ.; Johnson, SA., Li, Y., Yoder, MC. \& Feng, GS. (2003). A definitive role of Shp-2 tyrosine phosphatase in mediating embryonic stem cell differentiation and hematopoiesis. Blood, 102, 2074-80.

Chen, $X_{\text {, }}$ Xu, H., Yuan, P., Fang, F., Huss, M., Vega, VB., Wong, E., Orlov, YL., Zhang, W., Jiang, J., Loh, YH., Yeo, HC., Yeo, ZX., Narang, V., Govindarajan, KR., Leong, B., Shahab, A., Ruan, Y., Bourque, G., Sung, WK., Clarke, ND., Wei, CL. \& Ng, HH. (2008). Integration of external signaling pathways with the core transcriptional network in embryonic stem cells. Cell, 133, 1106-1117.

Czyz, J. \& Wobus, A. (2001). Embryonic stem cell differentiation: the role of extracellular factors. Differentiation, 68, 167-174.

Darnell, JE., Jr. (1997). STATs and gene regulation. Science, 277, 1630-1635.

$\mathrm{Du}, \mathrm{ZW}$. \& Zhang, SC. (2004). Neural differentiation from embryonic stem cells: which way? Stem Cells Dev., 13, 372-381.

Duval, D.; Reinhardt, B., Kedinger, C. \& Boeuf, H. (2000). Role of suppressors of cytokine signaling (Socs) in leukemia inhibitory factor (LIF)-dependent embryonic stem cell survival. FASEB J., 14, 1577-1584.

Ernst, M. \& Jenkins, BJ. (2004). Acquiring signaling specificity from the cytokine receptor gp130. Trends Genet., 20, 23-32.

Ernst, M.; Oates, A. \& Dunn, AR. (1996). gp130-mediated signal transduction in embryonic stem cells involves activation of Jak and Ras/mitogen-activated protein kinase pathways. J. Biol. Chem., 271, 30136-30143. 
Farah, MH.; Olson, JM., Sucic, HB., Hume, RI., Tapscott, SJ. \& Turner, DL. (2000). Generation of neurons by transient expression of neural bHLH proteins in mammalian cells. Development, 127, 693-702.

Forrai, A.; Boyle, K., Hart, AH., Hartley, L., Rakar, S., Willson, TA., Simpson, KM., Roberts, AW., Alexander, WS., Voss, AK. \& Robb, L. (2006). Absence of suppressor of cytokine signalling 3 reduces self-renewal and promotes differentiation in murine embryonic stem cells. Stem Cells, 24, 604-614.

Fukada, T.; Hibi, M., Yamanaka, Y., Takahashi-Tezuka, M., Fujitani, Y., Yamaguchi, T., Nakajima, K. \& Hirano, T. (1996). Two signals are necessary for cell proliferation induced by a cytokine receptor gp130: involvement of STAT3 in anti-apoptosis. Immunity, 5, 449-460.

Furuno, T.; Hamano. T. \& Nakanishi, M. (1993). Receptor-mediated calcium signal playing a nuclear third messenger in the activation of antigen-specific B cells. Biophys. J., 64, 665-669.

Furuno, T.; Hirashima, N., Onizawa, S., Sagiya, N. \& Nakanishi, M. (2001). Nuclear shuttling of mitogen-activated protein (MAP) kinase (extracellular signal-regulated kinase (ERK) 2) was dynamically controlled by MAP/ERK kinase after antigen stimulation in RBL-2H3 cells. J. Immunol., 166, 4416-4421.

Furuno, T.; Ito, A., Koma, Y., Watabe, K., Yokozaki, H., Bienenstock, J., Nakanishi, M. \& Kitamura, Y. (2005). The spermatogenic Ig superfamily/synaptic cell adhesion molecule mast-cell adhesion molecule promotes interaction with nerves. J. Immunol., 174, 6934-6942.

Gossen, M. \& Bujard, H. (1992). Tight control of gene expression in mammalian cells by tetracycline-responsive promoters. Proc. Natl. Acad. Sci. USA, 89, 5547-5551.

Gossen, M. \& Bujard, H. (1995). Efficacy of tetracycline-controlled gene expression is influenced by cell type: commentary. Biotechniques, 19, 213-216.

Heinrich, PC.; Behrmann, I., Haan, S., Hermanns, HM., Muller-Newen, G. \& Schaper, F. (2003). Principles of interleukin (IL)-6-type cytokine signalling and its regulation. Biochem. J., 374, 1-20.

Heinrich, PC.; Behrmann, I., Muller-Newen, G., Schaper, F. \& Graeve, L. (1998). Interleukin6-type cytokine signalling through the gp130/Jak/STAT pathway. Biochem. J., 334, 297-314.

Hibi, M.; Murakami, M., Saito, M., Hirano, T., Taga, T. \& Kishimoto, T. (1990). Molecular cloning and expression of an IL-6 signal transducer, gp130. Cell, 63, 1149-1157.

Ihara, S.; Nakajima, K., Fukada, T., Hibi, M., Nagata, S., Hirano, T. \& Fukui, Y. (1997). Dual control of neurite outgrowth by STAT3 and MAP kinase in PC12 cells stimulated with interleukin-6. EMBO J., 16, 5345-5352.

Ince-Dunn, G.; Hall, BJ., Hu, SC., Ripley, B., Huganir, RL., Olson, JM., Tapscott, SJ. \& Ghosh, A. (2006). Regulation of thalamocortical patterning and synaptic maturation by NeuroD2. Neuron, 49, 683-695.

Inoh, Y.; Kitamoto, D., Hirashima, N. \& Nakanishi, M. (2001). Biosurfactants of MEL-A increase gene transfection mediated by cationic liposomes. Biochem. Biophys. Res. Commun., 289, 57-61.

Jirmanova, L.; Afanassieff, M., Gobert-Gosse, S., Markossian, S. \& Savatier, P. (2002). Differential contributions of ERK and PI3-kinase to the regulation of cyclin D1 
expression and to the control of the G1/S transition in mouse embryonic stem cells. Oncogene, 21, 5515-5528.

Kanda, S.; Tamada, Y., Yoshidome, A., Hayashi, I. \& Nishiyama, T. (2004). Over-expression of bHLH genes facilitates neural formation of mouse embryonic stem (ES) cells in vitro. Int. J. Dev. Neurosci., 22, 149-156.

Kristensen, DM.; Kalisz, M. \& Nielsen, JH. (2005). Cytokine signalling in embryonic stem cells. APMIS, 113, 756-772.

Kume, H.; Maruyama, K., Tomita, T., Iwatsubo, T., Saido, TC. \& Obata, K. (1996). Molecular cloning of a novel basic helix-loop-helix protein from the rat brain. Biochem. Biophys. Res. Commun., 219, 526-530.

Li, J., Wang, G., Wang, C., Zhao, Y., Zhang, H., Tan, Z., Song, Z., Ding, M. \& Deng, H. (2007). MEK/ERK signaling contributes to the maintenance of human embryonic stem cell self-renewal. Differentiation, 75, 299-307.

Lin, CH.; Tapscott, SJ. \& Olson, JM. (2006). Congenital hypothyroidism (cretinism) in neuroD2-deficient mice. Mol. Cell. Biol., 26, 4311-4315.

Massari, ME. \& Murre, C. (2000). Helix-loop-helix proteins: regulators of transcription in eucaryotic organisms. Mol. Cell. Biol., 20, 429-440.

Matsuda, T.; Nakamura, T., Nakao, K., Arai, T., Katsuki, M., Heike, T. \& Yokota, T. (1999). STAT3 activation is sufficient to maintain an undifferentiated state of mouse embryonic stem cells. EMBO J., 18, 4261-4269.

McCormick, MB.; Tamimi, RM., Snider, L., Asakura, A., Bergstrom, D. \& Tapscott, SJ. (1996). NeuroD2 and neuroD3: distinct expression patterns and transcriptional activation potentials within the neuroD gene family. Mol. Cell. Biol., 16, 5792-5800.

Miyazu, S.; Furuno, T. \& Nakanishi, M. (2010). Phosphorylation states of STAT3 and ERKs in mouse embryonic stem cells. Cell Biol. Int., 34, 485-492.

Murashov, AK.; Pak, ES., Hendricks, WA., Owensby, JP., Sierpinski, PL., Tatko, LM. \& Fletcher, PL. (2005). Directed differentiation of embryonic stem cells into dorsal interneurons. FASEB J., 19, 252-254.

Nakanishi, M. (2003). New strategy in gene transfection by cationic transfection lipids with a cationic cholesterol. Curr. Med. Chem., 10, 1289-1296.

Nakanishi, M. \& Furuno, T. (2008). Molecular basis of neuroimmune interaction in an in vitro coculture approach. Cell. Mol. Immunol., 5, 249-259.

Nicholson, SE.; De Souza, D., Fabri, LJ., Corbin, J., Willson, TA., Zhang, JG., Silva, A., Asimakis, M., Farley, A., Nash, AD., Metcalf, D., Hilton, DJ., Nicola, NA. \& Baca, M. (2000). Suppressor of cytokine signaling-3 preferentially binds to the SHP-2binding site on the shared cytokine receptor subunit gp130. Proc. Natl. Acad. Sci. USA, 97, 6493-6498.

Niwa, H.; Burdon, T., Chambers, I. \& Smith, A. (1998). Self-renewal of pluripotent embryonic stem cells is mediated via activation of STAT3. Genes Dev., 12, 2048-2060.

Noda, T.; Kawamura, R., Funabashi, H., Mie, M. \& Kobatake, E. (2006). Transduction of NeuroD2 protein induced neural cell differentiation. J. Biotechnol., 126, 230-236.

Okita, K. \& Yamanaka, S. (2006). Intracellular signaling pathways regulating pluripotency of embryonic stem cells. Curr. Stem Cell Res. Ther., 1, 103-111.

Olson, JM.; Asakura, A., Snider, L., Hawkes, R., Strand, A., Stoeck, J., Hallahan, A., Pritchard, J. \& Tapscott, SJ. (2001). NeuroD2 is necessary for development and survival of central nervous system neurons. Dev. Biol., 234, 174-187. 
Qu, CK.; Shi, ZQ., Shen, R., Tsai, FY., Orkin, SH. \& Feng, GS. (1997). A deletion mutation in the SH2-N domain of Shp-2 severely suppresses hematopoietic cell development. Mol. Cell. Biol., 17, 5499-5507.

Raz, R.; Lee, CK., Cannizzaro, LA., d'Eustachio, P. \& Levy, DE. (1999). Essential role of STAT3 for embryonic stem cell pluripotency. Proc. Natl. Acad. Sci. USA, 96, 28462851.

Schindler, C. \& Darnell, JE., Jr. (1995). Transcriptional responses to polypeptide ligands: The JAK-STAT pathway. Annu. Rev. Biochem., 64, 621-651.

Schmitz, J.; Weissenbach, M., Haan, S., Heinrich, PC. \& Schaper, F. (2000). SOCS3 exerts its inhibitory function on interleukin-6 signal transduction through the SHP2 recruitment site of gp130. J. Biol. Chem., 275, 12848-12856.

Sengupta, TK.; Talbot, ES., Scherle, PA. \& Ivashkiv, LB. (1998). Rapid inhibition of interleukin- 6 signaling and Stat 3 activation mediated by mitogen-activated protein kinases. Proc. Natl. Acad. Sci. USA, 95, 11107-11112.

Smith, AG.; Heath, JK., Donaldson, DD., Wong, GG., Moreau, J., Stahl, M. \& Rogers D. (1988). Inhibition of pluripotential embryonic stem cell differentiation by purified polypeptides. Nature 336, 688-690.

Stahl, N.; Boulton, TG., Farruggella, T., Ip, NY., Davis, S., Witthuhn, BA., Quelle, FW., Silvennoinen, O., Barbieri, G., Pellegrini, S., Ihle, JN. \& Yancopoulos, GD. (1994). Association and activation of Jak-Tyk kinases by CNTF-LIF-OSM-IL-6 $\beta$ receptor components. Science, 263, 92-95.

Strubing, C.; Ahnert-Hilger, G., Shan, J., Wiedenmann, B., Hescheler, J. \& Wobus, AM. (1995). Differentiation of pluripotent embryonic stem cells into the neuronal lineage in vitro gives rise to mature inhibitory and excitatory neurons. Mech. Dev., 53, 275287.

Sugimoto, Y.; Furuno, T. \& Nakanishi, M. (2009). Effect of NeuroD2 expression on neuronal differentiation in mouse embryonic stem cells. Cell Biol. Int., 33, 174-179.

Suzuki, A.; Suzuki, R., Furuno, T., Teshima, R. \& Nakanishi, M. (2004). N-cadherin plays a role in the synapse-like structures between mast cells and neurites. Biol. Pharm. Bull., 27, 1891-1894.

Torres, J. \& Watt, FM. (2008). Nanog maintains pluripotency of mouse embryonic stem cells by inhibiting NFKB and cooperating with Stat3. Nat. Cell Biol., 10, 194-201.

Turkson, J.; Kim, JS., Zhang, S., Yuan, J., Huang, M., Glenn, M., Haura, E., Sebti, S., Hamilton, AD. \& Jove, R. (2004). Novel peptidomimetic inhibitors of signal transducer and activator of transcription 3 dimerization and biological activity. Mol. Cancer Ther., 3, 261-269.

Van Vactor, D.; O'Reilly, AM. \& Neel, BG. (1998). Genetic analysis of protein tyrosine phosphatases. Curr. Opin. Genet. Dev., 8, 112-126.

Williams, RL.; Hilton, DJ., Pease, S., Willson, TA., Stewart, CL., Gearing, DP., Wagner, EF., Metcalf, D., Nicola, NA. \& Gough NM. (1988). Myeloid leukaemia inhibitory factor maintains the developmental potential of embryonic stem cells. Nature, 336, 684687.

Wobus, AM., \& Boheler, KR. (2005). Embryonic stem cells: prospects for developmental biology and cell therapy. Physiol. Rev., 85, 635-678. 
Yao, Y.; Li, W., Wu, J., Germann, UA., Su, MS., Kuida, K. \& Boucher, DM. (2003). Extracellular signal-regulated kinase 2 is necessary for mesoderm differentiation. Proc. Natl. Acad. Sci. USA, 100, 12759-12764.

Yasunami, M.;, Suzuki, K., Maruyama, H., Kawakami, H., Nagai, Y., Hagiwara, M. \& Ohkubo, H. (1996). Molecular cloning and characterization of a cDNA encoding a novel basic helix-loop-helix protein structurally related to Neuro-D/BHF1. Biochem. Biophys. Res. Commun., 220, 754-758.

Ying, QL.; Nichols, J., Chambers, I. \& Smith, A. (2003). BMP induction of Id proteins suppresses differentiation and sustains embryonic stem cell self-renewal in collaboration with STAT3. Cell, 115, 281-292.

Ying, QL.; Wray, J., Nichols, J., Batlle-Morera, L., Doble, B., Woodgett, J., Cohen, P. \& Smith, A. (2008). The ground state of embryonic stem cell self-renewal. Nature, 453, 519523. 


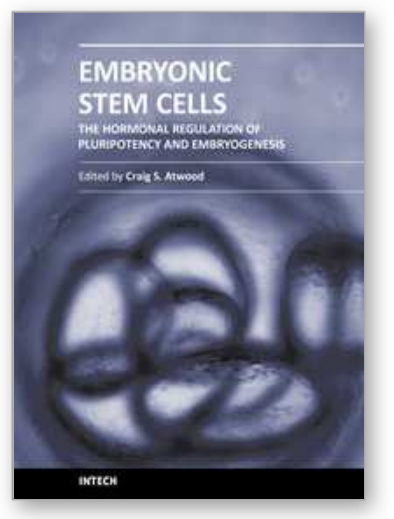

\section{Embryonic Stem Cells: The Hormonal Regulation of Pluripotency and Embryogenesis}

Edited by Prof. Craig Atwood

ISBN 978-953-307-196-1

Hard cover, 672 pages

Publisher InTech

Published online 26, April, 2011

Published in print edition April, 2011

Pluripotency is a prerequisite for the subsequent coordinated differentiation of embryonic stem cells into all tissues of the body. This book describes recent advances in our understanding of pluripotency and the hormonal regulation of embryonic stem cell differentiation into tissue types derived from the ectoderm, mesoderm and endoderm.

\section{How to reference}

In order to correctly reference this scholarly work, feel free to copy and paste the following:

Tadahide Furuno and Mamoru Nakanishi (2011). A Rational Approach to Inducing Neuronal Differentiation in Embryonic Stem Cells, Embryonic Stem Cells: The Hormonal Regulation of Pluripotency and Embryogenesis, Prof. Craig Atwood (Ed.), ISBN: 978-953-307-196-1, InTech, Available from:

http://www.intechopen.com/books/embryonic-stem-cells-the-hormonal-regulation-of-pluripotency-andembryogenesis/a-rational-approach-to-inducing-neuronal-differentiation-in-embryonic-stem-cells

\section{INTECH}

open science | open minds

\author{
InTech Europe \\ University Campus STeP Ri \\ Slavka Krautzeka 83/A \\ 51000 Rijeka, Croatia \\ Phone: +385 (51) 770447 \\ Fax: +385 (51) 686166 \\ www.intechopen.com
}

\author{
InTech China \\ Unit 405, Office Block, Hotel Equatorial Shanghai \\ No.65, Yan An Road (West), Shanghai, 200040, China \\ 中国上海市延安西路65号上海国际贵都大饭店办公楼 405 单元 \\ Phone: +86-21-62489820 \\ Fax: $+86-21-62489821$
}


(C) 2011 The Author(s). Licensee IntechOpen. This chapter is distributed under the terms of the Creative Commons Attribution-NonCommercialShareAlike-3.0 License, which permits use, distribution and reproduction for non-commercial purposes, provided the original is properly cited and derivative works building on this content are distributed under the same license. 